\title{
Correction to: Transcriptome and Gene Coexpression Network Analyses of Two Wild Populations Provides Insight into the High-Salinity Adaptation Mechanisms of Crassostrea ariakensis
}

\author{
Xingyu Liu ${ }^{1,3} \cdot \mathrm{Li} \mathrm{Li}^{1,2,5,6} \cdot$ Ao $\mathrm{Li}^{1,3} \cdot$ Yingxiang $\mathrm{Li}^{1,4,5,6} \cdot$ Wei Wang ${ }^{1,2,4,5,6} \cdot$ Guofan Zhang ${ }^{1,4,5,6}$
}

Published online: 5 August 2019

(C) Springer Science+Business Media, LLC, part of Springer Nature 2019

\section{Correction to: Mar Biotechnol}

https://doi.org/10.1007/s10126-019-09896-9

The original version of this article unfortunately contained a mistake in the authorgroup section. Letters A, B, C, D, E and F were inadvertently added before each author's name.

The original article has been corrected.

Publisher's note Springer Nature remains neutral with regard to jurisdictional claims in published maps and institutional affiliations.

The online version of the original article can be found at https://doi.org/ 10.1007/s10126-019-09896-9

Li Li

lili@qdio.ac.cn

1 Key Laboratory of Experimental Marine Biology, Institute of Oceanology, Chinese Academy of Sciences, Qingdao, Shandong, China

2 Laboratory for Marine Fisheries Science and Food Production Processes, Qingdao National Laboratory for Marine Science and Technology, Qingdao, Shandong, China

3 University of Chinese Academy of Sciences, Beijing, China

4 Laboratory for Marine Biology and Biotechnology, Qingdao National Laboratory for Marine Science and Technology, Qingdao, Shandong, China

5 Center for Ocean Mega-Science, Chinese Academy of Sciences, Beijing, China

6 National \& Local Joint Engineering Key Laboratory of Ecological Mariculture, Institute of Oceanology, Chinese Academy of Sciences, Qingdao, China 